\title{
Pelatihan untuk Meningkatan Semangat Green Entrepreneur pada Siswa Sekolah Menengah Atas
}

\author{
Etni Marliana ${ }^{1 *}$, Gilang Puspita Rini ${ }^{1}$ dan Faridhatun Faidah ${ }^{1}$ \\ ${ }^{1}$ Program Studi Manajemen, Universitas Muria Kudus, Jl. Lkr. Utara, Kayuapu Kulon, Gondangmanis, Kec. Bae, \\ Kabupaten Kudus, Jawa Tengah, Indonesia, 59327 \\ *Email koresponden: etni.marliana@umk.ac.id
}

\section{ARTICLE INFO \\ Article history \\ Received: 30 Jul 2020 \\ Accepted: 25 Mar 2021 \\ Published: 23 Apr 2021 \\ Kata kunci: \\ Green entrepreneur \\ Kewirausahaan \\ Siswa \\ Harga pokok penjualan}

\section{Keyword: \\ Green entrepreneur Entrepreneurship Students Cost of goods sold}

\begin{abstract}
A B S T R A K
Background: Green entrepreneur dibutuhkan untuk menjawab tantangan bisnis yang baru di abad 21. Adanya konsep green economy menuntut adanya lebih banyak wirausahawan yang membangun bisnis secara lebih berwawasan lingkungan. Metode: Pengabdian dilakukan dengan cara penyuluhan serta simulasi. Hasil: Hasil dari pengabdian ini adalah siswa dapat mempelajari karakteristik dari green entrepreneur, meningkatkan kreativitas dengan cara memproduksi barang menggunakan barang bekas, serta mempraktekkan menghitung biaya produksi dan harga pokok. Kesimpulan: sikap kreatif siswa terasah melalui simulasi pengolahan bahan bekas menjadi sesuatu yang bernilai ekonomis. Melalui simulasi tersebut siswa juga belajar cara menghitung biaya produksi dan harga pokok penjualan.
\end{abstract}

\section{A B S T R A C T}

Background: Green entrepreneurs are needed to answer new business challenges in the 21st century. The concept of green economy demands that more entrepreneurs build businesses in a more environmentally friendly manner. Methods: Community service was carried out by means of counseling and simulation. Results: The result of this dedication is that students can learn the characteristics of green entrepreneurs, increase creativity by producing goods using used goods, and practice calculating production costs and cost of goods. Conclusions: students' creative attitudes are honed through simulations of processing used materials into something of economic value. Through these simulations students also learn how to calculate production costs and cost of goods sold.

(C) 2021 by authors. Lisensi Jurnal Solma, UHAMKA, Jakarta. Artikel ini bersifat open access yang didistribusikan di bawah syara dan ketentuan Creative Commons Attribution (CC-BY) license.

\section{PENDAHULUAN}

Kewirausahaan dianggap sebagai hal yang penting bagi kemajuan suatu negara Menurut Lame et al., 2013; Santi et al., 2017 apabila setidaknya terdapat $\%$ penduduk suatu negara menjadi wirausahawan (entrepreneur), maka negara tersebut dapat mencapai kemakmuran (Citradewi \& Margunani., 2016). Namun demikian, di Indonesia jumlah wirausahawan hanya kurang dari 1\% dari total penduduk, jumlah tersebut masih sangat rendah. Banyak dari mahasiswa yang lebih berminat untuk bekerja di perusahaan besar (Marliana, 2018; Vivathuvahna \& Nugroho, 2015) ataupun bekerja sebagai pegawai negeri sipil (PNS) setelah mereka lulus kuliah. Berwirausaha menjadi pilihan terakhir ketika seseorang tidak diterima bekerja sebagai karyawan ataupun gagal menjadi PNS (Anisah, 2012). Hal ini dikarenakan para mahasiswa menganggap keamanan dari segi karir maupun keuangan dalam jangka panjang lebih bisa ditawarkan oleh perusahaan besar maupun PNS (Marliana, 2018). 
Banyak hal dapat menjelaskan mengapa seseorang kurang tertarik menjadi wirausahawan. Salah satunya anggapan bahwa sifat kewirausahan merupakan sesuatu yang dibawa sejak lahir. Anggapan tersebut membuat orang tidak menjadi wirausahaan karena merasa dirinya tidak dilahirkan dengan sifat-sifat seorang wirausahawan. Namun, penelitian menunjukkan bahwa kewirausahaan merupakan sesuatu yang dapat dipelajari (Purwanto, 2015). Menurut Mulyani et al. (2010) setiap manusia memiliki kemampuan dan kekuatan pada dirinya yang dapat digunakan untuk memenuhi kebutuhan serta memecahkan permasalahan hidup. Oleh karena itu, semua orang dapat menjadi wirausahawan apabila memanfaatkan kemapuan diri serta mempelajari dan memiliki pengetahuan tentang kewirausahaan. Menjadi wirausahawan berarti seseorang berani menggunakan kemampuan dan kekuatan diri untuk mempekerjakan diri sendiri, memulai, mengatur, mengelola, dan bertanggung jawab akan suatu usaha (Anisah, 2012).

Menurut Mulyani et al. (2010) proses yang ditawarkan untuk menumbuhkan jiwa wirausaha adalah dengan pengembangan individu secara bertahap. Tahapan tersebut dimulai dari kepedulian, pemahaman masalah nyata yang ada di masyarakat, knowledge dan keterampilan, penerapan dan penginstitusian. Karena pentingnya peran wirausahawan bagi kemajuan suatu negara, pengenalan kewirausahaan banyak dimulai dari bangku sekolah. Banyak Sekolah Menengah Atas (SMA) dan juga universitas di Indonesia telah memasukkan kewirausahaan dalam kurikulumnya. Diharapkan pemberian pembelajaran tersebut dapat membekali seorang individu untuk menumbuhkan jiwa kewirausahaan dalam diri mereka sejak dini.

Di sisi lain, saat ini, banyak terjadi perubahan dalam aspek bisnis dan lingkungan. Pada dekade ini penerapan konsep green economy sedang menjadi hal yang ditekankan di dunia bisnis (Anisah, 2012). Oleh karena itu yang menjadi perhatian bukan hanya membuat seseorang tertarik untuk menjadi wirausahawan. Namun juga, bagaimana seseorang dapat menjadi wirausahawan yang berwawasan lingkungan.

Konsep green economy menuntut adanya generasi wirausahawan baru yang memanfaatkan kesempatan tersebut (Farinelli et al., 2011). Hal ini berarti para wirausahawan dituntut untuk peduli terhadap permasalahan yang ada di masyarakat, utamanya yang terkait dengan isu/permasalahan lingkungan. Anisah (2012) mengungkapkan bahwa konsep green entrepreneurship memperhatikan aspek individu dan organisasi yang terlibat dalam aktivitas kewirausahaan untuk menciptakan manfaat bagi lingkungan. Para green entrepreneur menjalankan kegiatan wirausaha (menghasilkan barang/jasa) dengan memperhatikan keseimbangan antara aspek ekonomi, lingkungan dan masyarakat. Dengan demikian, mereka tidak hanya memproduksi barang/jasa untuk mendapatkan keuntungan semata. Namun, juga untuk menjalankan usaha yang membawa dampak yang lebih baik bagi lingkungan (Soenarto; et al., 2019). Para green entrepreneur mengangkat isu sosial dan menjadikan hal tersebut sebagai pusat aktivitas bisnis.

Bentuk kegiatan usaha dari para green entrepreneur sangat beragam. Beberapa diantaranya memulai usaha dengan menyasar isu lingkungan misalnya saja sampah. Untuk mengurangi jumlah sampah di bumi, beberapa green entrepreneur memanfaatkan sampah/barang bekas untuk diproduksi menjadi barang lain yang bermanfaat. Hal ini dilakukan untuk memperpanjang masa hidup suatu barang, sehingga barang tersebut tidak menjadi sampah dalam waktu dekat. Pemanfaatan sampah menjadi barang yang bermanfaat misalnya saja botol plastik bekas air mineral dapat digunakan sebagai media pembuatan taman vertikal atau vertical garden. Selain itu juga pemanfaatan plastik bungkus makanan dapat dibuat menjadi payung, tas, dan dompet (Asropah \& Ardiana, 2016). Lebih jauh lagi, saat ini usaha dari para green-entrepreneur sudah mulai merambah ke dunia online. Beberapa start-up didirikan untuk mengelola sampah, membuka bank sampah, dan tabungan sampah secara digital. 


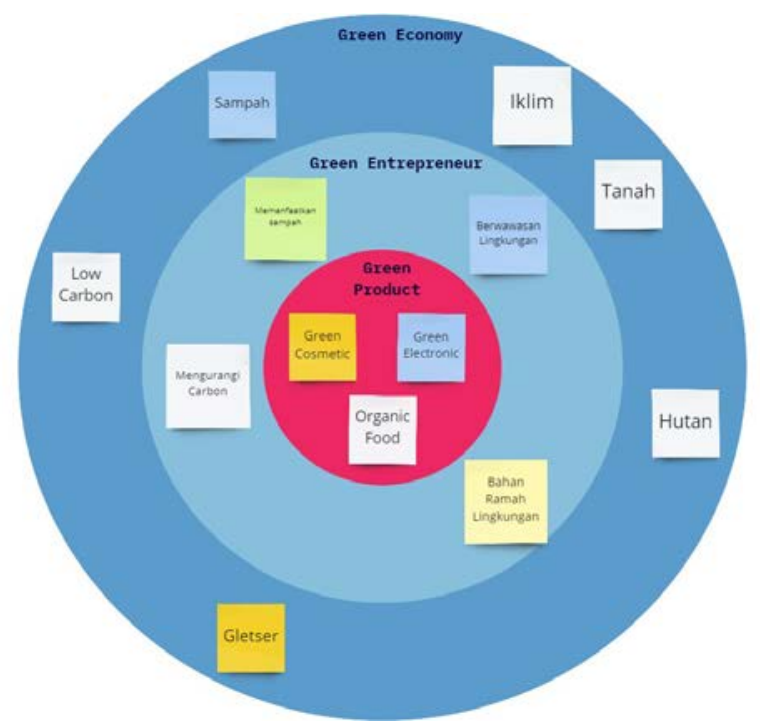

Gambar 1. Diagram green economy dan green entrepreneur

Bukan hanya memanfaatkan sampah, bentuk usaha dari para green entrepreneur lainnya misalnya saja menawarkan barang atau jasa yang lebih ramah lingkungan. Sebagai contoh, seorang green entrepreneur membuat produk dengan bahan-bahan alami, menggunakan kemasan dari bahan yang mudah terurai, dan menawarkan tempat wisata yang lebih ramah lingkungan. Dengan menggunakan barang yang lebih ramah lingkungan, diharapkan polusi dan juga limbah yang dihasilkan dari kegiatan usaha dapat diminimalisir.

Berbagai jenis usaha dari para green entrepreneur tersebut menunjukkan bahwa mereka memiliki kepedulian terhadap isu nyata yang ada di masyarakat terutama isu lingkungan. Mereka berusaha untuk menyelesaikan permasalahan tersebut melalui pengetahuan, keterampilan dan bisnis yang mereka bangun. Usaha yang mereka bangun tidak hanya memberikan dampak positif bagi pertumbuhan ekonomi, tetapi juga bagi lingkungan. Selama ini, walaupun membawa manfaat secara ekonomi, bisnis juga sering dikritisi karena membawa dampak buruk bagi lingkungan misalnya pencemaran dan juga limbah (Ridwan, 2016). Dengan semakin banyaknya green entrepreneur maka permasalahan lingkungan yang timbul dari adanya bisnis diharapkan dapat semakin diminimalisir.

SMA 1 Kudus merupakan salah satu sekolah yang memberikan mata pelajaran kewirausahaan kepada para siswanya. Mata pelajaran tersebut diberikan setiap satu minggu sekali selama 2 kali jam pelajaran (2x45 menit) kepada siswa kelas X, XI dan kelas XII. Dalam mata pelajaran tersebut, para siswa diajarkan empat materi utama, yaitu materi pengolahan, kerajinan, budidaya dan rekayasa. Dengan mempelajari hal-hal tersebut, para siswa belajar tentang sikap kreatif yang dibutuhkan oleh para wirausahawan. Menurut salah satu guru pengampu mata pelajaran kewirausahaan, siswa sebagian besar tertarik dengan materi pengolahan karena prosesnya produksinya yang lebih cepat. Di samping itu, hasil pengolahan (terutama jenis makanan) dirasa dapat dipasarkan secara lebih mudah.

Siswa SMA dipilih dalam program pengabdian ini karena dalam usia tersebut seseorang biasanya sudah mulai berpikir tentang karir. Oleh karena itu, penanaman jiwa entrepeneur terutama konsep green entrepreneur tepat diberikan sejak dini, saat siswa ada di bangku SMA. Diharapkan dengan bertambahnya wawasan mengenai green entrepreneur para siswa SMA dapat menjadi lebih tertarik untuk terjun ke dunia bisnis yang mengangkat masalah - masalah lingkungan.

Kegiatan pengabdian kepada masyarakat yang dilakukan memiliki beberapa tujuan. Pertama, kegiatan ini dilakukan untuk membantu mengenalkan green entrepreneurship kepada 
para siswa. Hal ini dilakukan karena dalam mata pelajaran kewirausahaan yang ditawarkan, konsep green entrepreneurship belum diajarkan. Tujuan lainnya adalah untuk memanfaatkan barang bekas, untuk memberikan pengetahuan kepada para siswa tentang penentuan biaya dan harga pokok penjualan. Dengan pemanfaatan barang bekas dalam proses belajar, siswa diharapkan dapat memupuk kreativitas siswa untuk mengelola barang bekas menjadi sesuatu yang bermanfaat dan bernilai bisnis.

\section{MASALAH}

Dalam pelaksanan mata pelajaran kewirausahaan masih ditemukan beberapa kesulitan. Para siswa belum mengenal tentang green entrepreneurship, sehingga ketertarikan mereka untuk menjadi wirausahawan yang memiliki wawasan lingkungan masih rendah. Padahal tantangan bisnis sekarang ini semakin berubah. Pengembangan bisnis secara berkelanjutan menjadi salah satu isu penting diabad 21 (Fors \& Taro, 2019). Bisnis dituntut untuk dapat menjadi lebih hijau dan berwawasan lingkungan.

Permasalahan lain yang dihadapi oleh para siswa adalah mereka masih kesulitan untuk menghubungkan pengetahuan kewirausahaan yang mereka telah pelajari dengan praktek seharihari. Dalam pelajaran para siswa telah berhasil untuk membuat suatu produk. Namun demikian, mereka masih mengalami kesulitan dalam penentuan harga barang yang mereka produksi. Keuntungan dapat menjadi kurang maksimal apabila harga yang ditetapkan kurang tepat.

\section{METODE PELAKSANAAN}

Kegiatan pengabdian kepada masyarakat dilakukan dengan metode ceramah, simulasi, dan diskusi.

1. Penyuluhan

Peserta diberikan pemaparan mengenai green entrepreneur utamanya tentang pengertian, karakteristik, dan jenis-jenis bisnis dari green entrepreneur. Setelah itu, para siswa juga diberi pemaparan mengenai jenis-jenis biaya, cara menghitung biaya produksi, serta cara perhitungan harga pokok penjualan dari suatu barang.

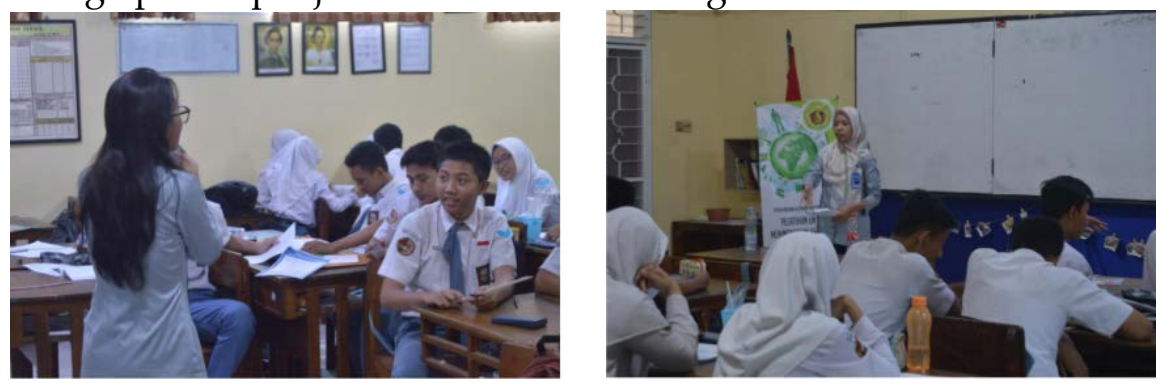

Gambar 2. Pemaparan materi green entrepreneurship

2. Simulasi

Setelah diberikan pemaparan, siswa diajak untuk melakukan simulasi. Simulasi dilakukan dengan cara memanfaatkan barang bekas dengan tujuan untuk menunjukkan kepada para siswa bahwa barang bekas dapat bermanfaat dan memiliki nilai ekonomi apabila diolah dengan baik. Dalam simulasi tersebut siswa dibagi dalam 6 kelompok. Setiap kelompok diberikan uang-uangan sebagai modal dalam melakukan proses produksi. Mereka dapat memilih bahan baku berupa bahan bekas dan membeli peralatan serta perlengkapan lain yang digunakan untuk pengolahan.

Setiap kelompok diharuskan membuat satu macam produk dari bahan bekas yang dipilih dan peralatan yang telah dibeli. Setelah itu mereka harus menghitung biaya dari barang yang mereka buat dan menetapkan harga produk yang mereka jual. Perhitungan 
biaya dan penetapan harga dituliskan dalam lembar evaluasi yang dibagikan. Produk kemudian harus dapat dijual dengan cara mempresentasikannya kepada para pembeli (dalam hal ini tim pelaksana pengabdian) di depan kelas.
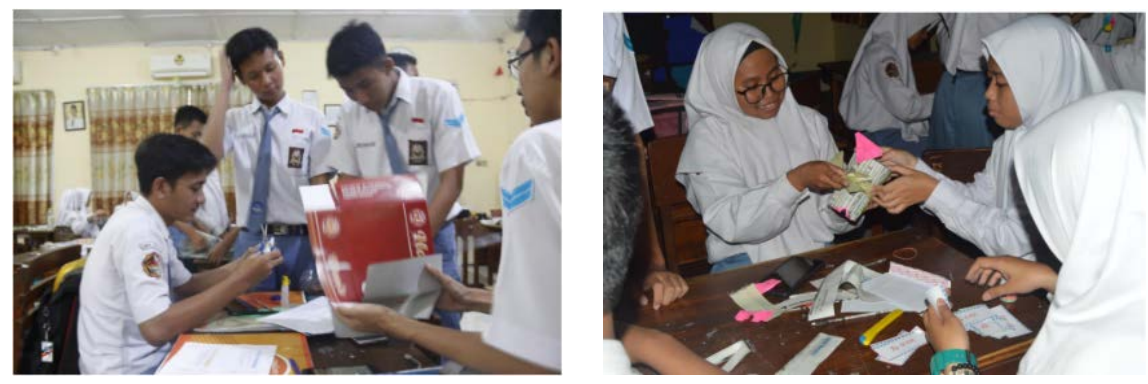

Gambar 3. Simulasi pembuatan produk dengan barang bekas dan perhitungan harga

3. Diskusi

Diskusi dilakukan setelah simulasi selesai dilakukan. Diskusi dilakukan untuk menjawab pertanyaan-pertanyaan siswa mengenai materi dan simulasi yang disampaikan.

\begin{tabular}{|c|c|}
\hline $\begin{array}{l}\text { Perencanaan } \\
\text { - Merencanakan pelatihan tentang } \\
\text { - Mreen Entrepreneur } \\
\text { - Membuat modul penyuluhan. } \\
\text { Menyiapkan bahan kegiatan dalam }\end{array}$ & $\begin{array}{l}\text { Penyuluhan } \\
\text { - Siswa kelas XI SMA } 1 \text { Kudus diberikan } \\
\text { penyuluhan tentang green entrepreneur dan } \\
\text { penentukan harga pokok penjualan. }\end{array}$ \\
\hline & $\downarrow$ \\
\hline $\begin{array}{l}\text { Diskusi } \\
\text { Tanya jawab tentang hal-hal yang } \\
\text { belum dipahami oleh para siswa. }\end{array}$ & $\begin{array}{l}\text { Simulasi } \\
\text { Simulasi proses produksi barang dan penentuan } \\
\text { biaya produksi, dan harga barang mengunakan } \\
\text { barang bekas }\end{array}$ \\
\hline \multicolumn{2}{|l|}{$\downarrow$} \\
\hline \multicolumn{2}{|c|}{$\begin{array}{l}\text { Evaluasi } \\
\text { Memberi lembar kerja untuk mengetahui pemahaman siswa tentang materi yang telah diberikan. } \\
\text { Mencatat kekurangan, kelemahan yang muncul dalam proses pelatihan peningkatan semangat } \\
\text { green entrepreneur }\end{array}$} \\
\hline
\end{tabular}

Gambar 4. Alur Realisasi Pengabdian Kepada Masyarakat

\section{HASIL DAN PEMBAHASAN}

Peserta dari pengabdian ini adalah 30 siswa SMA Kelas XI SMA N 1 Kudus. Para siswa bertindak sebagai peserta aktif partisipasitoris dimana mereka mendengarkan pemaparan dari tim pengabdian, kemudian diajak untuk berpartisipasi dalam simulasi (learning by doing) (Nuraeni \& Lelly., 2020). Materi dan simulasi diberikan oleh tiga dosen Fakultas Ekonomi dan Bisnis Universitas Muria Kudus.

Di awal penyampaian materi, sebagian besar siswa belum pernah mendengar istilah green entrepreneur maupun green entrepreneurship. Dalam pemaparan kaitannya dengan hal tersebut, tim pengabdian menjelaskan apa yang dimaksud dengan green entrepreneurship, karakteristik green entrepreneur, dan bentuk-bentuk bisnis dari para green entrepreneur. Selain itu siswa juga dibekali dengan materi pentingnya melakukan perhitungan harga pokok dalam berwirausaha serta bagaimana cara melakukan strategi penjualan yang menarik di pasar saat ini. 
Sesi pemaparan materi juga dilengkapi dengan sesi tanya jawab. Pada bagian ini siswa lebih antusias dalam memahami apa itu green entrepreneur. Dengan adanya komunikasi dua arah tersebut, memberikan bukti bahwa ada informasi yang diterima oleh peserta pengabdian. Pada tahap pengenalan mengenai green entrepreneur, penekanan utama kami adalah pada karakteristik green entrepreneur, sehingga peserta dapat memahami dan dapat meningkatkan ketertarikan untuk menjadi seorang green entrepreneur. Beberapa karakteristik green entrepreneur yang kami sampaikan kepada peserta antara lain: dapat memiliki ide yang inovatif, dengan memikirkan aspek risiko; memiliki sensitivitas terhadap permasalahan lingkungan; memiliki aktivitas bisnis yang memiliki efek baik terhadap lingkungan dan juga dapat menghasilkan keuntungan finansial. Dengan memahami karakteristiknya, siswa tidak hanya bisa membayangkan, tetapi dapat menerapkan didalam diri masing- masing peserta.

Selain dengan pemaparan, penyampaian tentang kewirausahaan kepada para siswa diperdalam dengan adanya simulasi di sesi kedua. Di sesi simulasi, para siswa terlihat lebih antusias mengikuti. Hal ini dimungkinkan karena dengan simulasi para siswa diajak untuk belajar sambil mempraktekkan sehingga tidak hanya tentang teori (Kusmanto, 2014). Pada sesi pertama telah disampaikan bahwa karakterisitik green entrepreneur diantaranya adalah ide yang inovatif dan sensitivitas terhadap permasalahan lingkungan. Simulasi di sesi kedua dilakukan dengan tujuan untuk mengasah kedua hal tersebut dari para siswa. Detail peraturan dalam simulasi dapat dilihat pada gambar 5.

Dalam simulasi mahasiswa diberikan uang-uangan sebagai modal awal. Uang-uangan tersebut dibuat untuk memberikan gambaran bahwa untuk menjalankan sebuah usaha, seorang wirausahawan akan membutuhkan modal yang digunakan untuk membeli peralatan, perlengkapan, membayar tenaga kerja, dll. Selain itu, simulasi dilakukan dengan menggunakan berbagai macam bahan bekas yang harus diolah menjadi barang yang memiliki nilai ekonomis. Penggunaan barang bekas bertujuan untuk meningkatkan sensitivitas para siswa terhadap permasalahan lingkungan. Sedangkan aktivitas pengolahan barang bekas menjadi nilai ekonomis dilakukan dengan tujuan untuk mengasah kreativitas dan kemampuan inovasi para siswa untuk menemukan produk yang layak jual.

Para siswa dapat memproduksi beberapa barang yang memiliki nilai ekonomis menggunakan barang bekas dalam waktu yang telah disediakan. Barang-barang yang diproduksi oleh para siswa misalnya saja tempat pensil, tempat tissue, hiasan ruangan. Walaupun masih cukup sederhana, produk-produk tersebut dapat ditingkatkan kualitasnya dengan waktu produksi yang lebih banyak. Selain itu, dengan dihasilkannya produk-produk tersebut membuktikan bahwa dengan kreativitas, barang yang sudah dibuang dapat dimanfaatkan menjadi barang lain. Hal ini diharapkan dapat meningkatkan sensitivitas para siswa untuk membangun bisnis dengan lebih memperhatikan dampaknya terhadap lingkungan.

Selesai melakukan produksi barang, para siswa diberi waktu untuk menghitung total biaya yang dikeluarkan dan juga harga jual barang yang ditetapkan untuk suatu barang. Perhitungan tersebut dilakukan dengan menggunakan lembar evaluasi (gambar 6) yang diberikan oleh tim pengabdian. Pemberian lembar perhitungan ini dimaksudkan untuk menyampaikan pada para siswa bahwa dalam melakukan kegiatan wirausaha, perhitungan biaya secara tepat dibutuhkan untuk bisa menentukan harga jual.

Perhitungan biaya yang kurang tepat oleh wirausahawan, dapat berpengaruh terhadap kurang tepatnya penentuan harga jual. Bisa saja harga jual menjadi terlalu tinggi, yang menyebabkan konsumen menjadi kurang tertarik terhadap barang tersebut. Namun, bisa juga harga jual terlalu murah sehingga keuntungan menjadi kurang maksimal. Dalam lembar evaluasi terdapat kotak untuk menuliskan harga jual riil yang diterima. Hal ini dilakukan karena pada praktiknya, kadang terdapat barang yang tidak dapat terjual dengan sesuai dengan target harga. 
Seorang wirausahawan harus dapat membuat keputusan apakah akan tetap bertahan dengan harga awal yang ditetapkan atau akan menjual harga barang dibawah target harga. Kemampuan untuk membuat keputusan dengan tepat juga dibutuhkan oleh para wirausahan untuk dapat menjalankan usahanya dengan baik.

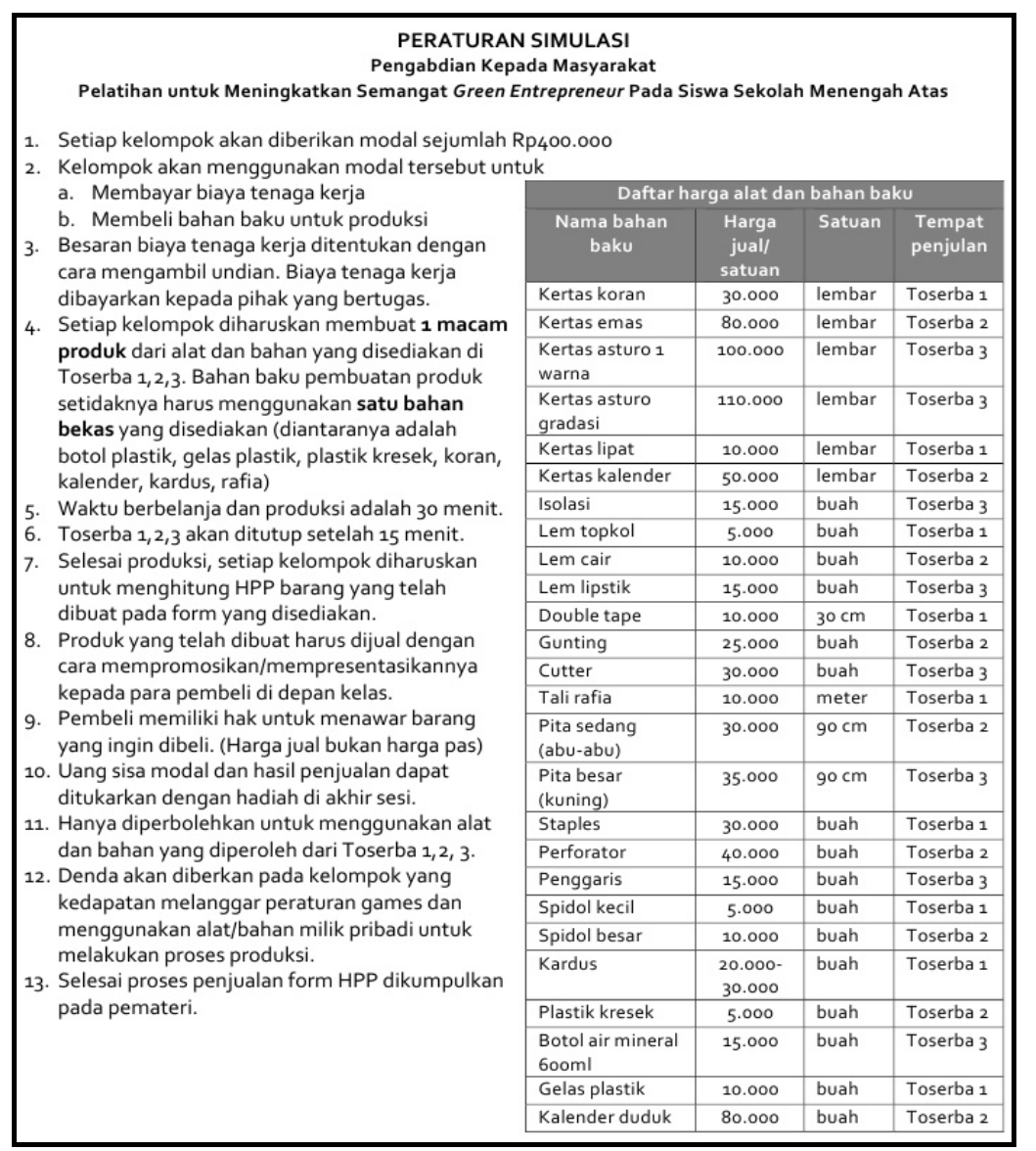

Gambar 5. Peraturan yang digunakan dalam simulasi pembuatan produk dengan barang bekas dan perhitungan harga

Selesai menetapkan harga jual, para siswa diberi kesempatan untuk menjual produknya kepada para pembeli yang dalam hal ini adalah tim pengabdian. Proses penjualan produk dilakukan dengan cara melakukan presentasi untuk meyakinkan para pembeli membeli produk. Pembeli kemudian akan membeli barang pada tingkat harga yang dianggap sesuai. Apabila harga dianggap terlalu tinggi oleh pembeli, maka pembeli pun dapat melakukan penawaran agar harga menjadi lebih murah. Kegiatan presentasi produk dalam simulasi dilakukan untuk melatih kemampuan komunikasi dan meyakinkan para siswa. Wirausahawan akan membutuhkan kemampuan berkomunikasi secara meyakinkan untuk dapat menarik konsumen membeli dan memakai produk yang dia jual.

Pada tahapan simulasi ini pula siswa dibekali cara melakukan strategi penjualan yang menarik konsumen seperti pemberian promo yang terbatas, harga diskon, bonus pembelian dalam jumlah pembelian tertentu. Yang terpenting adalah bahwa barang harus tetap terjual di akhir meskipun dengan harga minimal dari harga pokok penjualan yang telah ditetapkan. Selain itu seorang wirausahawan juga diwajibkan untuk melakukan evaluasi terhadap hasil penjualan dan membandingkannya dengan perencanaan yang telah dilakukan sebelumnya. Evaluasi dilakukan untuk melihat apakah produk telah dibuat dan dijual dengan harga yang sesuai harapan atau 
justru sebaliknya. Hal ini diperlukan agar untuk pembuatan produk selanjutnya, siswa dapat belajar dari pengalaman sebelumnya agar mendapatkan hasil yang lebih baik.

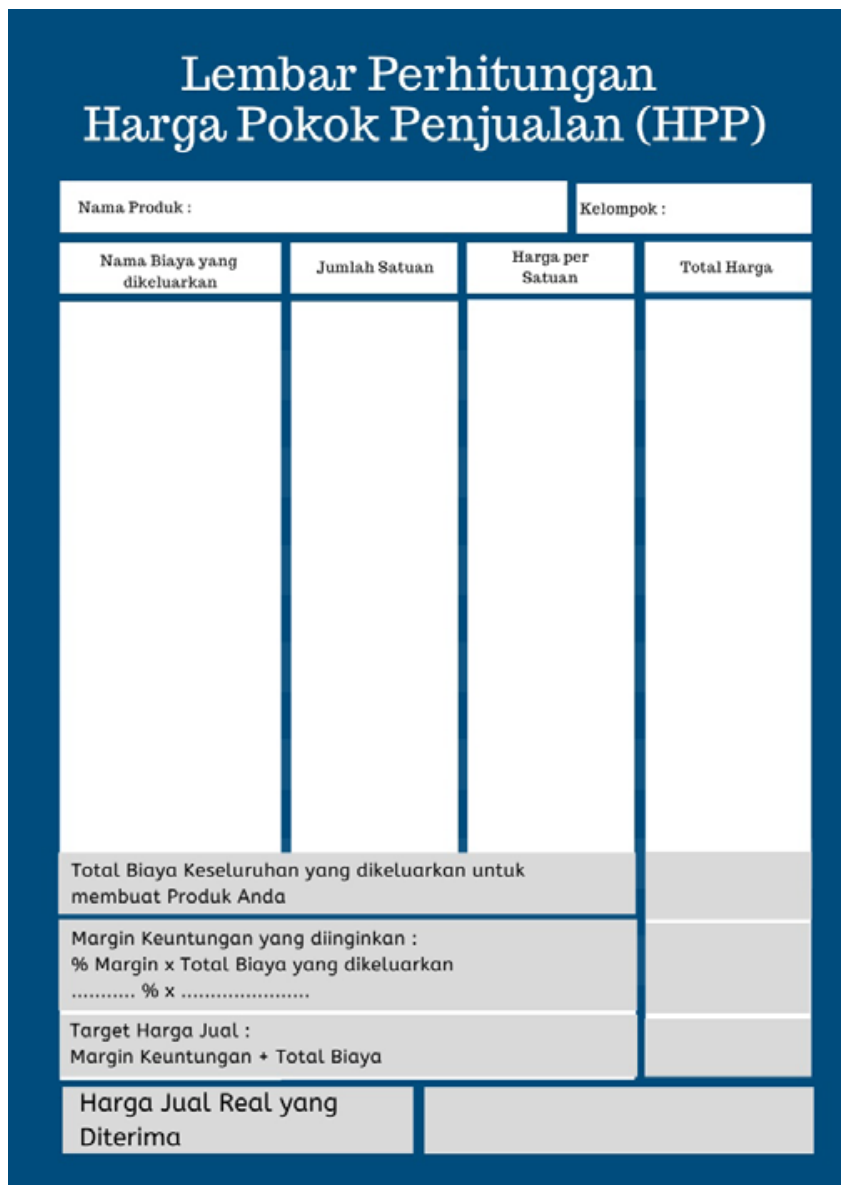

Gambar 6. Lembar evaluasi perhitungan harga pokok penjualan

Dari lembar evaluasi yang diisi oleh para siswa diketahui bahwa para siswa telah mengetahui bagaimana cara menghitung biaya produksi dan menentukan harga pokok penjualan. Permasalahan utama adalah beberapa kelompok hanya menghitung biaya bahan baku dan peralatan yang digunakan. Akan tetapi, mereka belum memperhitungkan biaya tenaga pembuatan barang dalam perhitungan biaya produksi. Oleh karena itu, untuk pengabdian selanjutnya perlu ditekankan lagi bahwa biaya tenaga kerja juga perlu diperhitungkan dalam perhitungan biaya walaupun produksi dilakukan oleh diri sendiri.

Terdapat beberapa hal yang dipelajari oleh para siswa melalui kegiatan pengabdian ini. Misalnya saja, para siswa belajar karakteristik dan pengertian dari green entrepreneur. Selain itu, para siswa belajar untuk berpikir kreatif dan inovatif untuk membuat suatu produk dari barang bekas. Para siswa juga belajar untuk menghitung biaya produksi barang serta membuat keputusan untuk menentukan harga jual. Kemampuan berkomunikasi untuk meyakinkan pembeli membeli produk juga dipelajari siswa dalam kegiatan ini.

Secara umum para siswa merasa puas dengan kegiatan pengabdian ini. Namun, terdapat beberapa hal yang perlu ditingkatkan. Pertama, penyampaian materi yang tentang green entrepreneur dibuat secara lebih menarik bukan hanya dengan menggunakan presentasi dan power point. Akan lebih menarik bagi siswa jika mereka bisa mendengar pemaparan langsung mengenai bisnis yang ramah lingkungan dari seorang green entrepreneur. Kedua, waktu pengabdian bisa diperpanjang menjadi beberapa kali pertemuan secara berkelanjutan. Dengan 
lebih banyaknya waktu, materi dan kegiatan yang bisa diperoleh para siswa juga akan lebih banyak.

\section{KESIMPULAN}

Kegiatan pengabdian pelatihan untuk meningkatan semangat green entrepreneur diikuti dengan cukup antusias oleh para siswa SMA 1 Kudus. Siswa mendapatkan pengetahuan dasar mengenai konsep green entrepreneur seperti cara menghitung biaya produksi dan harga pokok penjualan. Kegiatan ini juga meningkatkan kreativitas siswa dalam mengolah bahan bekas menjadi sesuatu yang bernilai ekonomis. Semakin tinggi ketertarikan siswa tentang green entrepreneur maka terdapat kemungkinan bahwa beberapa diantara mereka dapat menjadi wirausahawan yang berorientasi pada lingkungan di masa depan.

\section{UCAPAN TERIMA KASIH}

Penulis mengucapkan terimakasih kepada pihak-pihak yang membantu suksesnya penyelenggaraan pengabdian masyarakat ini, terutama kepada mitra SMA 1 Kudus.

\section{DAFTAR PUSTAKA}

Anisah, H. U. (2012). Pembentukan Green Entrepeneurial Behavior pada mahasiswa. Jurnal Ekonomi Dan Keuangan, 19(3), 397-415.

Asropah, I. S. I., \& Ardiana, E. (2016). Pemanfaatan Barang Bekas Botol Plastik dalam Pembuatan Vertical Garden. E-Dimas: Jurnal Pengabdian Kepada Masyarakat, 7(2), 9-16.

Citradewi, A., \& Margunani. (2016). Pengaruh Kepribadian, Pendidikan Kewirausahaan, dan Lingkungan Keluarga Terhadap Aktivitas Berwirausaha Mahasiswa Universitas Negeri Semarang. Economic Education Analysis Journal, 5(2), 519-531.

Farinelli, F. B., Marino;, Akkoyunlu, S., \& Aerni, P. (2011). Green Entrepreneurship: The Missing Link Towards a Greener Economy. ATDF JOURNA, 8(3), 42-48.

Fors, P. L., \& Taro, T. (2019). The Individual-Care Nexus: A Theory of Entrepreneurial Care for Sustainable Entrepreneurship. Sustainability, 11, 1-18.

Kusmanto, A. S. S. (2014). Pendekatan Learning By Doingdalam Pembelajaran Fisika Dengan Media Riil Dan Multimedia Interaktif Ditinjau Dari Kreativitas Dan Motivasi Berprestasi. Jurnal Inkuiri, 3(3), 65-74.

Lame, S. M., Fauziah, W., \& Yusoff, W. (2013). The Perception of Students Towards Entrepreneurship Courses: An Empirical Study of Nigerian Polytechnics Students.

Marliana, E. (2018). Ketertarikan dan Persepsi Mahasiswa Fakultas Ekonomika dan Bisnis untuk Bekerja di Usaha Kecil Menengah. Jurnal Bisnis Dan Manajemen, 11(1), 33-46.

Mulyani, E., Lestari, B., Wahyuni, D. B., \& Kiromim. (2010). Pelatihan Pemanfaatan Barang Bekas Sebagai Media Pembelajaran Ekonomi. Inotek, 14(2), 167-180.

Nuraeni, H. A. Q., \& Lelly. (2020). Mendidik Anak Era Digital di Perguruan Muhammadiyah Parakan Tangerang Selatan. Jurnal SOLMA, 9(1), 26-32.

Purwanto, M. I. (2015). Pengaruh Kompetensi Dosen Dan Sikap Mahasiswa Pada Mata Kuliah Kewirausahaan Terhadap Tumbuhnya Jiwa Enterpernuer Mahasiswa Dalam Penerapan Project Based Learning. Jurnal Probisnis, 8(2), 1-15.

Ridwan, I. (2016). Dampak Industri terhadap Lingkungan dan Sosial. Jurnal Geogragi Gea, 7(2).

Santi, N. H., Amir, \& Rahmawati, T. (2017). Pengaruh Efikasi Diri, Norma Subjektif, Sikap Berperilaku, dan 
Pendidikan Kewirausahaan Terhadap Intensi Berwirausaha. Jurnal Inspirasi Bisnis Dan Manajemen, 1(1), 63-74.

Soenarto;, Rahmawati;, Suprapti, A. R. H., Rum, Sudira, \& Putu. (2019). Green Entrepreneurship Development Strategy Based On Local Characteristic To Support Eco-Tourism Continuous. Jurnal Manajemen, 23(2), 257-273.

Vivathuvahna, A. A., \& Nugroho, T. R. D. A. (2015). Intensi Kewirausahaan Mahasiswa Universitas Trunojoyo Madura. Agriekonomika, 4(1), 107-119. 